Original Contribution

\title{
EFFECTS OF TEMPERATURE AND DESICCATION ON SURVIVAL RATE OF HAEMONCHUS CONTORTUS INFECTIVE LARVAL STAGE
}

\author{
P. T. Iliev*, A. Ivanov, P. Prelezov \\ Department of Veterinary Microbiology, Infectious and Parasitic Diseases, Faculty of Veterinary \\ Medicine, Trakia University, Stara Zagora, Bulgaria
}

\begin{abstract}
Small ruminants are among the most commonly farmed livestock in Bulgaria. The climate and geographic conditions and pastoral way of growing lead to higher infestation of herds by variety of soil-transmitted helminths. The most spread nematodes are gastro-intestinal strongylids (GIS) causing various diseases of sheep and goats. Abomasal parasite Haemonchus contortus (Nematoda, Trichostrongylidae) constitutes a major part of gastro-intestinal helminthic fauna of small ruminants and is one of the most pathogenic members of this family causing serious economic losses of sheep and goat farms. Pre-parasitic period of $H$. contortus consisting of segmented eggs, non-infective larvae first and second stage (L1, L2) and infective larvae (L3). This development is also known as exogenous phase and takes place only in environment. Presence of viable and infective L3 on pastures is fully depended on climate conditions, solar radiation, grass and soil type etc. However, temperature and humidity are the most important factors exerting a marked effect on survival of $H$. contortus L3 on pastures. Resistance of L3 to some atmospheric variables e.g. temperature and humidity could be used to predict occurrence of haemonchosis among small ruminants. The present study aimed to investigate the effect of temperature and desiccation on L3 vitality of $H$. contortus under laboratory conditions. Experimental infection in lambs by $H$. contortus was reproduced. Feces were collected after beginning of the patent period of infection. Fecal samples were cultivated for 10 days at $27^{\circ} \mathrm{C}$ for developing infective $\mathrm{L} 3$ which were then obtained by routine Baermann technique. Acquired L3 were placed under various temperatures $\left(-4^{\circ} \mathrm{C} ;-18^{\circ} \mathrm{C} ; 40^{\circ} \mathrm{C} ; 45^{\circ} \mathrm{C} ; 50^{\circ} \mathrm{C}\right)$ and desiccation. The results clearly showed that $\mathrm{L} 3$ were more resistant to desiccation, $-4^{\circ}$ and $40^{\circ} \mathrm{C}$ and less to $-18^{\circ} \mathrm{C}, 45^{\circ} \mathrm{C}$ and $50^{\circ} \mathrm{C}$.
\end{abstract}

Key words: Haemonchus contortus, infective larvae, desiccation, temperature

\section{INTRODUCTION}

Vitality and infectivity of strongylid L3 in environment depends on cumulative effect of the three main atmospheric variables, namely temperature, humidity and ultraviolet (solar) radiation, which directly influence on larvae survival rate and therefore regulate their bioavailability of pastures. The presence of protective sheath and ability of larvae to perform horizontal and vertical migration represent a kind of adaptative mechanism limiting somewhat the harmful effects of unfavorable climate factors (1). According to Todd et al. (2), only $1 \%$ of infective $H$. contortus larvae survive more than 24 hours at $-10^{\circ} \mathrm{C}$. In a similar experiment, Jasmer et al. (3)

\footnotetext{
*Correspondence to: $P$. T. Iliev, Department of Veterinary Microbiology, Infectious and Parasitic Diseases, Faculty of Veterinary medicine, Trakia University, 6000 Stara Zagora, Bulgaria, tel: +359 42699 587,E-mail: petyo_todorow@abv.bg
}

evaluate the effect of freezing (at $-10^{\circ} \mathrm{C}$ for 15 hours) followed by incubation $\left(3^{\circ} \mathrm{C}\right.$ for 9 hours) on the vitality level of $H$. contortus infective larvae. The authors found no living L3 on day 14 after the temperature cycle. Gruner et al. (4) affirmed that the larvae retain vital for 300 days at $20^{\circ} \mathrm{C}$, and the highest survival rate $(95 \%)$ is observed between $150^{\text {th }}$ and $180^{\text {th }}$ day. The results of similar studies revealed that over $90 \%$ of $H$. contortus larvae survive for 10 weeks at $3^{\circ} \mathrm{C}(3,5)$.

Vital $H$. contortus L3 were isolated from pasture on day 93 at $12^{\circ} \mathrm{C}$ and at high relative humidity (5). Data presented in the same investigation also showed a significant larval reduction on day 9 at $28^{\circ} \mathrm{C}$ and $35 \%$ relative humidity. Similar results were also obtained by Carneiro et al. (6) who reported that $H$. contortus larvae survive on pastures for several weeks in average monthly temperatures of around $17^{\circ} \mathrm{C}$. Zajac (7) and Morgan et al. (8) 
summarized the data on studies performed earlier and concluded the increasing temperature leads to reduction of L3 both in environment and under laboratory conditions. The authors assumed the presence of cuticle layer inhibits an access of nutritive elements to the larva and hence L3 survival is fully depended on its own energy reserve stored into the intestine cells. Heat accelerates larval metabolic processes which resulting on faster depletion of available nutrients and decreasing survival rate. In this relation, Todd et al. (2) found only $7 \%$ alive $H$. contortus $\mathrm{L} 3$ at $45^{\circ} \mathrm{C}$ for two days. Protective sheath defends the larvae not only from unfavorable temperature but also from desiccation (5, 9). However, repeated dehydration affects Trichostrongylus colubriformis larvae worse than single influence (10). In contrast, Lettini et al. (11) affirmed that the process of drying followed by rehydration (known as anhydrobiosis) does not cause significant injury of infective larvae. Furthermore, the survival rate is extended due to reduction of metabolic activity. However, multiple and prolonged anhydrobiosis reduces the vitality of $H$. contortus L3 (12).

\section{MATERIALS AND METHODS}

Infective larvae were acquired from experimentally infected with $H$. contortus lambs. Prior to the study, an approval for using animals in experiment was obtained from the Bulgarian Food Safety Agency (permit No. 107). Feces were collected after beginning the patent period of infection. Fecal samples were cultivated for 10 days at $27^{\circ} \mathrm{C}$ for developing of infective L3 which were then obtained by routine Baermann technique. Acquired infective larvae were exposed to different variation of temperature and desiccation (Table 1). Key criteria in assessing the harmful effects were changes in the larval morphology and behavior such as paleness and destruction of intestinal cells, bubble inclusions in larval body, flexions or corrugation onto the larva and changes in motility.

Table 1. Influence of temperature and desiccation on L3 of H. contortus

\begin{tabular}{|c|c|}
\hline & Influence \\
\hline 1 & $\begin{array}{l}\text { Freezing at }-4^{\circ} \mathrm{C} \text { and }-18^{\circ} \mathrm{C} \text { for } 12,24,48,72 \text { and } 96 \text { hours followed by } \\
\text { cultivation at } 27^{\circ} \mathrm{C} \text { for } 6 \text { hours }\end{array}$ \\
\hline 2 & $\begin{array}{l}\text { Double-freezing at }-18^{\circ} \mathrm{C} \text { for } 12 \text { hours each followed by cultivation at } \\
27^{\circ} \mathrm{C} \text { for } 6 \text { hours }\end{array}$ \\
\hline 3 & $\begin{array}{l}\text { 3-fold freezing at }-4^{\circ} \mathrm{C} \text { for } 12 \text { hours each followed by cultivation at } \\
27^{\circ} \mathrm{C} \text { for } 6 \text { hours }\end{array}$ \\
\hline 4 & Storage at $4^{\circ} \mathrm{C}$ for 15 months \\
\hline 5 & $\begin{array}{l}\text { Heating at } 40^{\circ} \mathrm{C}, 45 \text { and } 50 \text { for } 15 \text { days, } 2 \text { days and } 24 \text { hours, } \\
\text { respectively }\end{array}$ \\
\hline 6 & Drying at room temperature from 1 to 12 hours followed by hydration \\
\hline 7 & $\begin{array}{l}\text { 6-fold drying for } 1 \text { hour each at room temperature followed by } \\
\text { hydration }\end{array}$ \\
\hline
\end{tabular}

\section{RESULTS}

Temperature of $40^{\circ} \mathrm{C}$ negatively correlated with the survival rates of $H$. contortus L3. In addition, the same temperature value did not significantly affect the larvae vitality and motility during the first 3 days (Table 2). Prolonged heating also induced an exsheating of larvae (Figure 1) which were paler and the border between intestinal cells was unclear (Figure 2). Decreased motility was observed on day 10 after heating. No mobile larvae were detected on day 14 and 15 . Heating of L3 at higher temperatures $\left(45^{\circ} \mathrm{C}\right.$ and $\left.50^{\circ} \mathrm{C}\right)$ caused $100 \%$ lethality as early on hour 48 and 24 of exposure, respectively. Data obtained by influence of low temperatures on L3 vitality are presented in Table 3. Only $18.1 \%$ of L3 were alive after storing at $4^{\circ} \mathrm{C}$ for 15 months.
Immotile larvae were filled with bubbles over the entire body length and the intestinal cells were fully degenerated (Figure 3).

The single drying did not adversely affect L3 until $3^{\text {rd }}$ hours at the beginning of experiment and more than half L3 retain the active movements. A sharp decline in number of motile larvae was observed at $4^{\text {th }}$ hour. The most of L3 were exsheated and broken in places was also presented. Twice drying stored the most larvae (72.2\%) and differences compared to single influence were negligible $(2.8 \%)$. Larvae were actively motile and time needed for motility reversion was significantly short (a few seconds). Later, L3 slowly regained their mobility but integrity of intestinal cells was impaired (Table 4). 
ILIEV P. T. et al.

Table 2. Effect of $40^{\circ} \mathrm{C}$ and duration period (DP) on vitality of H. contortus L3

\begin{tabular}{|c|c|c|c|c|c|c|c|c|c|c|c|c|c|c|c|}
\hline DP (days) & 1 & 2 & 3 & 4 & 5 & 6 & 7 & 8 & 9 & 10 & 11 & 12 & 13 & 14 & 15 \\
\hline \% Vital L3 & $\begin{array}{l}\overrightarrow{8} \\
09\end{array}$ & $\begin{array}{l}\overrightarrow{8} \\
8 \\
0\end{array}$ & $\begin{array}{l}\text { b } \\
d^{9}\end{array}$ & $\begin{array}{l}\text { जे } \\
\text { ì } \\
\text { do }\end{array}$ & $\begin{array}{l}\text { पr } \\
\text { 6े } \\
\text { d9 }\end{array}$ & $\begin{array}{l}\omega \\
\vec{b} \\
\text { do } \\
d^{q}\end{array}$ & $\begin{array}{l}\tilde{o}^{2} \\
\text { dq }\end{array}$ & 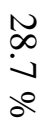 & $\begin{array}{l}\stackrel{D}{A} \\
d 8\end{array}$ & $\begin{array}{l}N \\
\omega \\
+ \\
d Q\end{array}$ & $\begin{array}{l}\overrightarrow{0} \\
\dot{v} \\
0\end{array}$ & $\begin{array}{l}\vec{t} \\
\overrightarrow{0}\end{array}$ & $\begin{array}{l}\vec{N} \\
\stackrel{\omega}{0} \\
j^{q}\end{array}$ & 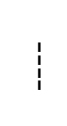 & 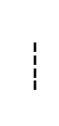 \\
\hline
\end{tabular}

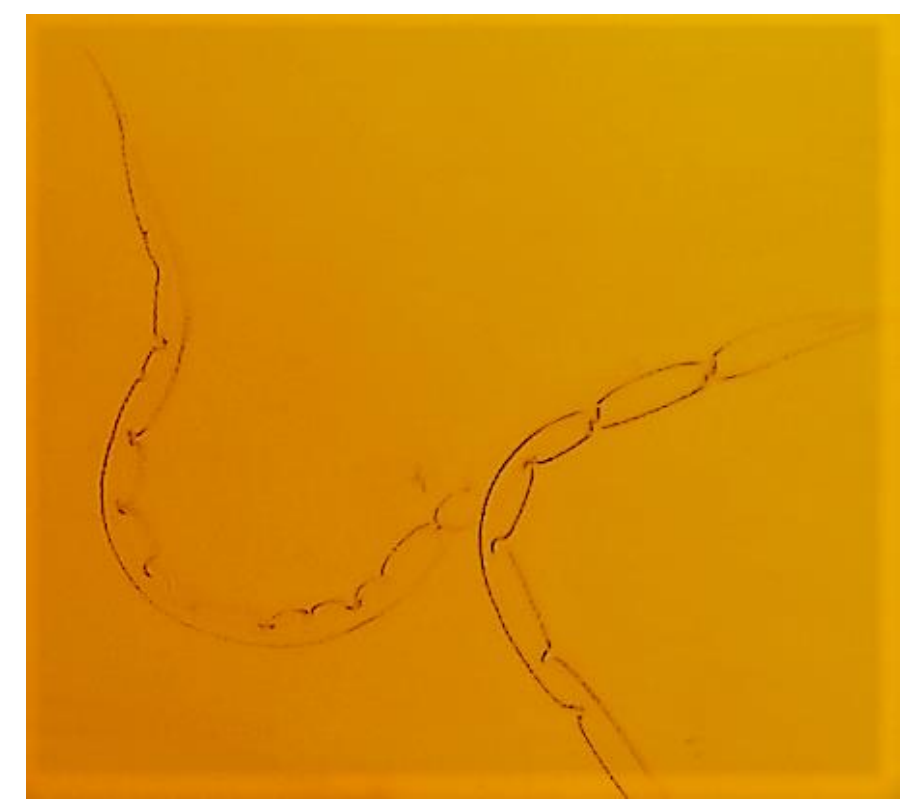

Figure 1. Protective sheaths of $H$. contortus infective larvae after heating

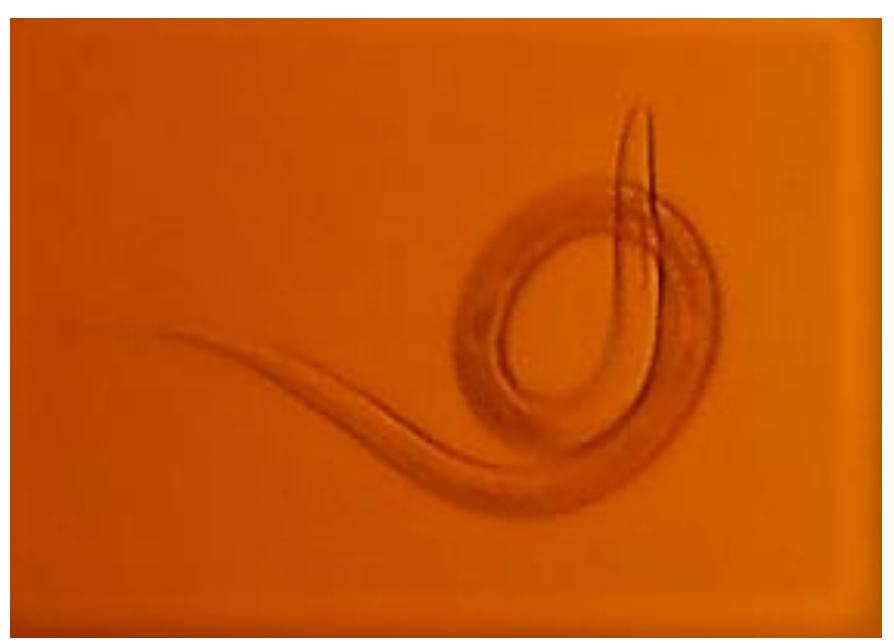

Figure 2. Exsheathed $H$. contortus L3 after heating

Table 3. Influence of low temperatures on vitality of $H$. contortus $L 3$

\begin{tabular}{|c|c|c|c|}
\hline LT & $\begin{array}{c}\text { Exposure } \\
\text { (hours) }\end{array}$ & Times & \% vital L3 \\
\hline \multirow{7}{*}{$-18^{0} \mathrm{C}$} & \multirow[b]{2}{*}{12 hours each } & \multirow[b]{2}{*}{ Twice } & $5.7 \%$ \\
\hline & & & --- \\
\hline & 12 & \multirow{5}{*}{ 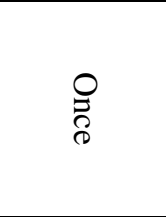 } & $5.7 \%$ \\
\hline & 24 & & $2.7 \%$ \\
\hline & 48 & & $2.2 \%$ \\
\hline & 72 & & $\begin{array}{l}-- \\
\end{array}$ \\
\hline & 96 & & --- \\
\hline \multirow{8}{*}{$-4^{0} \mathrm{C}$} & \multirow{3}{*}{12 hours each } & \multirow{3}{*}{ Three-fold } & $28.6 \%$ \\
\hline & & & $23.5 \%$ \\
\hline & & & --- \\
\hline & 12 & \multirow{5}{*}{$\begin{array}{l}\stackrel{0}{8} \\
\varnothing\end{array}$} & $28.6 \%$ \\
\hline & 24 & & $4.8 \%$ \\
\hline & 48 & & $3.3 \%$ \\
\hline & 72 & & --- \\
\hline & 96 & & --- \\
\hline
\end{tabular}




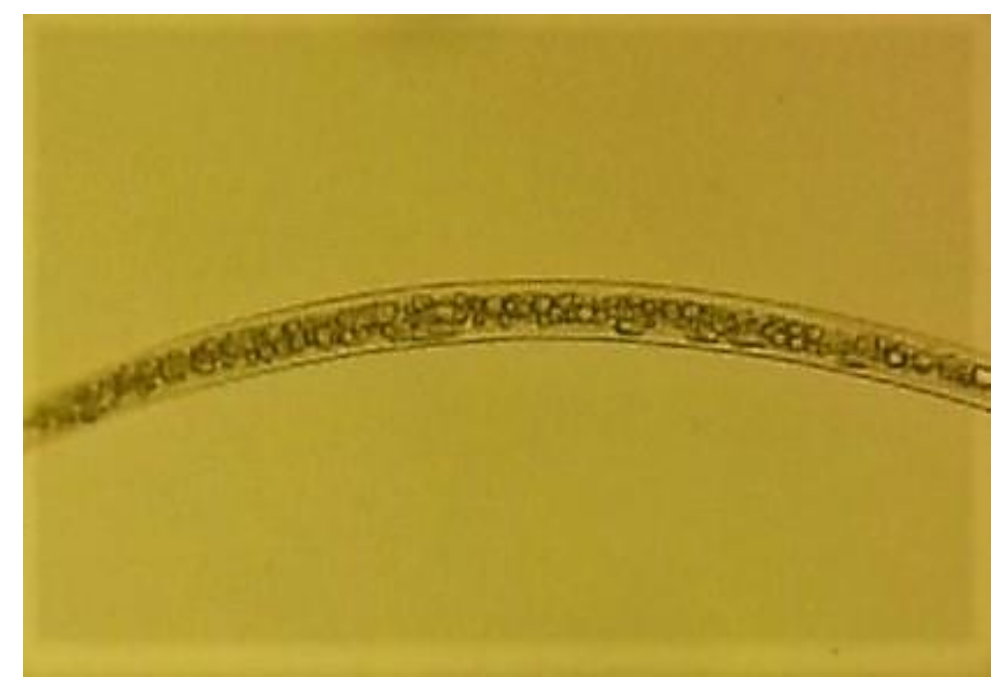

Figure 3. Bubble degeneration of $H$. contortus L3 after prolonged storage

Table 4. Influence of desiccation on vitality of $H$. contortus $L 3$

\begin{tabular}{|c|c|c|c|c|c|c|}
\hline $\begin{array}{c}\text { Duration } \\
\text { (hour) }\end{array}$ & 1 & 2 & 3 & 4 & 5 & 6 \\
\hline \% vital L3 & $79.5 \%$ & $75 \%$ & $53.6 \%$ & $30 \%$ & $11.8 \%$ & $10 \%$ \\
\hline Times & 1 & 2 & 3 & 4 & 5 & 6 \\
\hline \% vital L3 & $75 \%$ & $72.2 \%$ & $30.6 \%$ & $2.1 \%$ & -- & -- \\
\hline
\end{tabular}

\section{DISCUSSION}

Our results showed that temperatures above $40^{\circ} \mathrm{C}$ significantly influence larvae mortality. It is in agreement with data of Anderson et al. (13) who affirmed the infective larvae of Trichostrongylus spp. quickly die at $45^{\circ} \mathrm{C}$ and $50^{\circ} \mathrm{C}$. In similar investigation Todd et al. (2) also reported a high mortality of $H$. contortus $\mathrm{L} 3$ at $45^{\circ} \mathrm{C}$ for 2 days while only $7 \%$ remained alive. Zajac (7) and Morgan et al. (8) also found that increasing temperature reduced the survival rate of strongylid larvae. The authors assumed that the presence of sheath inhibits an access of nutritive elements to the larva and thus L3 survival is fully depended on its own energy reserve stored into the intestine cells. Heat accelerates larval metabolic processes which resulting on faster depletion of available nutrients and decreasing survival rate. It is well known that the enzyme system operates under strictly defined upper and lower temperature limits. Higher temperature levels cause denaturation of the enzymes which are also proteine molecules and lead to a collapse on the metabolic processes.

Our data also demonstrated the freezing at $18^{\circ} \mathrm{C}$ greatly reduce the larval vitality and only $2.7 \%$ of L3 survived for 24 hours. Similar results were presented by Todd et al. (2) who reported that only $1 \%$ of $H$. contortus L3 remained alive at $-10^{\circ} \mathrm{C}$ for 24 hours. According to Andersen et al. (13), L3 of Trichostrongylus colubriformis survived for 8 days at the same temperature. The results presented in this study are also in agreement to published by Jasmer et al. (3) and Pandey et al. (14) who compared the temperature resistance rate between $\mathrm{L} 3$ of $H$. contortus and Teladorsagia circumcincta.

Our data demonstrated that only $18.1 \%$ of L3 were alive after storing at $4^{\circ} \mathrm{C}$ for 15 months. This fully coincide with results of Andersen et al. (13) who revealed that L3 of Trichostrongylus spp. survived 425 days at $4^{\circ} \mathrm{C}$. In this relation, over $90 \%$ of $H$. contortus $\mathrm{L} 3$ remained alive at $3^{\circ} \mathrm{C}$ for 10 weeks $(3,5)$.

Relatively high resistance of L3 to variations of humidity was attributed to the presence of additional cuticle layer functioning as biological shield protecting larvae from drying out $(5,9)$. However, repeated dehydration affects Trichostrongylus colubriformis L3 worse than single influence (10). In contrast, Lettini et al. (11) affirmed that anhydrobiosis does not cause significant injury of infective larvae. Furthermore, the survival rate is extended due to reduction of metabolic activity. However, multiple and prolonged anhydrobiosis reduces the vitality of $H$. contortus L3 (12). Those reports coincide with our results which demonstrated that $53.6 \%$ of L3 withstand once drying for a period of 3 hours. Moreover, twice dehydration does not cause a significantly harm and many of larvae $(72.2 \%)$ retain vital. 
CONCLUSION

Freezing at $-18^{\circ} \mathrm{C}$ is the most important factor affecting the survival rate of $H$. contortus $\mathrm{L} 3$ than temperatures of $-4^{\circ} \mathrm{C}$ and $40^{\circ} \mathrm{C}$ as well as desiccation. Therefore, the climate conditions in Bulgaria favor the prolonged survival period of larvae on pastures during all seasons. Moreover, the ability of L3 to perform horizontal and vertical migration further multiplies the risk of occurrence of haemonchosis among small and large ruminants during summer.

\section{REFERENCES}

1. Stromberg, B., Environmental factors influencing transmission. Vet Parasitol, 72:247-264, 1997.

2. Todd, K. S. Jr., Levine, N. D., Boatman, P. A., Effect of temperature on survival of free-living stages of Haemonchus contortus. Am J Vet Res, 37:991-992, 1976.

3. Jasmer, D., Wescott, R. B., Crane, J. W., Survival of third-stage larvae of Washington isolates of Haemonchus contortus and Ostertagia circumcincta exposed to cold temperatures. Proc Helminthol Soc Wash, 54:48-52, 1987.

4. Gruner, L., and Suryahadi, S., Irrigation, faecal water content and development rate of free-living stages of sheep trichostrongyles. Vet Res, 24:327-334, 1993.

5. O'Connor, L. J., Walkden-Brown, S. W., Kahn, L. P., Ecology of the free-living stages of major trichostrongylid parasites of sheep. Vet Parasitol, 142:1-15, 2006.

6. Carneiro, R. D. C., and Amarante, A. F. T., Seasonal effect of three pasture plant species on the free-living stages of
Haemonchus contortus. Arq Bras Med Vet Zootec, 60:864-872, 2008.

7. Zajac, A. M., Gastrointestinal nematodes of small ruminants: Life cycle, anthelmintics, and diagnosis. Vet Clin North Am Food Anim Pract 22:529-541, 2006.

8. Morgan, E. R., and van Dijk, J., Climate and the epidemiology of gastrointestinal nematode infections of sheep in Europe. Vet Parasitol, 189:8-14, 2012.

9. Ellenby, C., Dormancy and survival in nematodes. Symp Soc Exp Biol, 23:83-97, 1968.

10.Schmidt, J. M., Todd, K. S. Jr., Levine, N. D., Moisture stress effects on survival of infective Trichostrongylus colubriformis larvae. J Nematol, 6:27-29, 1974.

11.Lettini, S. E., and Sukhedeo, V. K., Anhydrobiosis increases survival of trichostrongyle nematodes. J Parasitol, 92:1002-1009, 2006.

12.Siamba, D. N., Gatongi, P. M., Mulambalah, C. S., Ngeiywa, M. M., Wamae, L. W., Wambugu, A., Changes in lipids utilisation during moisture and temperature stress of infective $\left(\mathrm{L}_{3}\right)$ and its implication on the epidemiology of Haemonchus contortus in arid and semi arid lands. Curr Res J Biol Sci, 3:88-94, 2011.

13.Andersen, F. L., Wang, G. T. Levine, N. D., Effect of temperature on survival of the free-living stages of Trichostrongylus colubriformis. J Parasitol, 52:713-721, 1966.

14.Pandey, V. S., Chaer, A., Dakkak, A., Effect of temperature and relative humidity on survival of eggs and infective larvae of Ostertagia circumcincta. Vet Parasitol, 49:219-227, 1993. 